Article

\title{
Effects of TaPHS1 and TaMKK3-A Genes on Wheat Pre-Harvest Sprouting Resistance
}

\author{
Meng Lin ${ }^{1,2}$, Shubing Liu ${ }^{1,3}$, Guorong Zhang ${ }^{1}$ and Guihua Bai ${ }^{1,4, *(D)}$ \\ 1 Agronomy Department, Kansas State University, 2004 Throckmorton Hall, Manhattan, KS 66506, USA; \\ lemonsquirrel1987@gmail.com (M.L.); sbliu@sdau.edu.cn (S.L.); gzhang@ksu.edu (G.Z.) \\ 2353 Plant Science, Plant Breeding and Genetics, Cornell University, Ithaca, NY 14850, USA \\ 3 Department of Agriculture, Shandong Agricultural University, Taian 271018, China \\ 4 Hard Winter Wheat Genetics Research Unit, USDA-ARS, 4008 Throckmorton Hall, \\ Manhattan, KS 66506, USA \\ * Correspondence: guihua.bai@ars.usda.gov; Tel.: +1-785-532-1124
}

Received: 31 August 2018; Accepted: 28 September 2018; Published: 30 September 2018

\begin{abstract}
Pre-harvest sprouting (PHS) constrains wheat production worldwide by reducing both wheat grain yield and end-use quality. TaPHS1 on wheat chromosome 3AS and TaMKK3- $A$ on chromosome 4AL are two cloned genes with major effects on PHS resistance and they are independent from grain color (GC). In this study, we used marker-assisted backcrossing (MAB) to introgress TaPHS1 and TaMKK3-A from two PHS resistant sources-'Tutoumai A' and 'AUS1408' - into a sprouting-susceptible white wheat line, NW97S186. Progeny were tested in four environments to investigate individual and combined effects of those two genes. TaPHS1 significantly reduced PHS and its effect on PHS varied with environments and gene sources. In contrast, the TaMKK3- $A$ gene also significantly reduced PHS but its effectiveness was influenced by environments. The two genes had additive effects on PHS resistance, indicating pyramiding those two quantitative trait lici (QTLs) could increase PHS resistance. The additive effects were greater in a mild environment, such as a greenhouse, than in a dry and hot environment during maturation.
\end{abstract}

Keywords: Triticum aestivum; pre-harvest sprouting; TaPHS1; TaMKK3-A; combined genetic effect

\section{Introduction}

Pre-harvest sprouting (PHS), the germination of physiologically matured grains before harvesting, has been a major problem that causes significant reduction in grain yield and end-use quality in wheat (Triticum aestivum L.) [1-3]. PHS resistance is a complex trait controlled by several major quantitative trait loci (QTLs) and many minor QTLs. QTLs for PHS resistance have been reported on almost all wheat chromosomes, among which causal genes for the non-grain color (GC) related QTLs on chromosome 3AS (QPhs.ocs-3A.1) and 4AL (Phs1) have been cloned and designated as TaPHS1 [4,5] and TaMKK3-A [6], respectively. TaPHS1, annotated as a MOTHER OF FLOWERING TIME (TaMFT)-like gene, is the causal gene of a major PHS resistance QTL identified in hard white wheat cultivar Rio Blanco [5,7] and positively regulates wheat PHS resistance. Three single nucleotide polymorphisms (SNPs) have been associated with its PHS resistance. One SNP in the promoter region $(-222)$ increases seed dormancy at low temperatures during seed development [4]. Two other SNPs in the gene-coding region $(+646,+666)$ decrease seed dormancy by generating a mis-splicing site and a premature stop codon, respectively, to form a truncated nonfunctional transcript and thus increase PHS susceptibility [5]. Further, these mutations in TaPHS1 might be involved in wheat domestication [8] to meet the need of prompt and uniform germination in wheat production. Another major gene TaMKK3- $A$ [6], previously designated as Phs1, on chromosome arm 4AL for both PHS resistance and 
seed dormancy was reported in both white and red wheat [2,9-16]. A mitogen-activated protein kinase kinase 3 (MKK3) has been cloned as the candidate gene [6]. A single SNP that causes a nonsynonymous amino acid substitution in the kinase domain was reported to be the functional SNP in the gene [6]. To avoid confusion between TaPHS1 and Phs1, we use TaPHS1 for the gene on 3AS and TaMKK3-A for the gene on 4AS hereafter. Although several other QTLs have been reported to be associated with PHS resistance [17-19], only TaPHS1 and TaMKK3-A have been cloned and validated to show major effects in multiple backgrounds [4-6,15].

MFT has been considered a negative regulator of ABA sensitivity for seed germination in Arabidopsis [20] and TaPHS1 is proposed as a messenger that coordinates performance between tissues in seed germination [4]. Similarly, protein kinases play critical roles in signal transduction pathways and MKK genes are important in protein phosphorylation in ABA signaling [6]. However, the mechanisms by which TaPHS1 and TaMKK3-A interact to regulate seed dormancy and PHS resistance is still unknown. The objective of the current study was to investigate the individual and combined genetic effects of the two genes by transferring TaPHS1 and TaMKK3-A individually or together into a white PHS-susceptible wheat line using marker-assisted backcross (MAB) and testing the progeny in different environments.

\section{Materials and Methods}

\subsection{Plant Materials and PHS Evaluation}

'Tutoumai A' is a Chinese landrace [12] and 'AUS1408' is a spring wheat accession from South Africa. Both are white-grained wheat and have been used as PHS-resistant parents to map the PHS resistance QTL (TaMKK3- $A$ ) on chromosome 4A [12]. Although the 3A QTL was not detected in those studies, both accessions carried the TaPHS1 resistance allele when they were assayed with the TaPHS1 gene marker [8]. Therefore, Tutoumai A and AUS1408 were used as the donors for both TaPHS1 and TaMKK3-A. NW97S186, a PHS-susceptible hard white winter wheat breeding line developed by the USA Department of Agriculture-Agricultural Research Service at the Lincoln, NE, USA was used as the common recurrent parent. The backcross procedure is described in Figure S1. In brief, Tutoumai A and AUS1408 were crossed to NW97S186, respectively, to obtain (Tutoumai A $\times$ NW97S186) F1 and (AUS1408 $\times$ NW97S186) F1. Their F1 plants were backcrossed to NW97S186 twice to develop $\mathrm{BC} 2 \mathrm{~F} 1$ plants. The double heterozygous plants for both genes in the BC1F1 plants and BC2F1 plants were selected using two gene markers in the TaPHS1 coding region [8] and one SNP tightly linked to TaMKK3-A [21] (Table S2). The selected plants were used for further backcrossing or generation advancement. At least 10 heterozygous plants at both gene loci were identified among the BC2F1's in each cross. The selected $\mathrm{BC} 2 \mathrm{~F} 1$ plants were selfed to generate the double homozygous $\mathrm{BC} 2 \mathrm{~F} 2$ and BC2F3 lines (Figure S1), which were used to evaluate germination rate. The TaMKK3- $A$ gene marker was used to confirm the genotype carrying the 4A QTL for PHS evaluation [6] (Table S2).

\subsection{Pre-Harvest Sprouting Evaluation}

In the greenhouse experiments, five plants from each selected $\mathrm{BC} 2 \mathrm{~F} 2$ and $\mathrm{BC} 2 \mathrm{~F} 3$ family and their parental lines were grown in a 13 by $13 \mathrm{~cm}$ Dura-pot (Hummert Inc., Topeka, KS, USA) under the growth conditions listed in Table S1 after vernalization for seven weeks at $6{ }^{\circ} \mathrm{C}$ in a cold chamber. PHS was accessed in the greenhouse experiments of fall August-December 2015 and spring January-May 2016 in Kansas State University, Manhattan, KS, USA.

The selected BC2F2 and BC2F3 lines and their parental lines were also planted for evaluation of PHS resistance at the Kansas State University Rocky Ford Wheat Research Farm, Manhattan, KS, USA and the Agricultural Research Center-Hays, Hays, KS, USA respectively, in summer 2016. Thirty seeds per line were planted in a 1.22-m-long single-row plot with three replications.

When wheat plants reached physiological maturity (Zadoks scale 91) [22], spikes that lost green color [23] were harvested from both greenhouse and field experiments and evaluated for 
PHS in the laboratory. Five spikes per accession were air-dried for 5 days in a greenhouse and then stored at $-20^{\circ} \mathrm{C}$ to maintain dormancy for PHS evaluation. After all accessions had been collected, the greenhouse-harvested spikes were air-dried 9 days and field-harvested spikes for 5 days at room temperature, which were determined based on preliminary test to maximize phenotypic differences among genotypes. After the dried spikes had been immersed in de-ionized water for $12 \mathrm{~h}$, they were enclosed in a moist chamber at $22 \pm 1{ }^{\circ} \mathrm{C}$ with an attached humidifier that ran twice daily for $2 \mathrm{~h}$ each time to maintain high moisture in the chamber. After 7 days of incubation, the spikes were hand-threshed and germinated and non-germinated kernels were counted separately to calculate the percentage of germinated kernels for each accession [7].

\subsection{Statistical Analysis}

Four-way analysis of variance (ANOVA) was conducted using PROC GLM procedure in SAS 9.3 (SAS institute Inc., Cary, NC, USA) with environment, gene source and genotypes of TaPHS1 and TaMKK3- $A$ as fixed effects. Environments referred to the four experiments and gene sources referred to the two donors, Tutoumai A and AUS1408. Only homozygous genotypes of the TaPHS1 and TaMKK3-A genes were phenotyped, with lower-case letters for PHS-susceptible alleles and upper-case letters for PHS-resistant alleles. Least-squared means were compared using the F-protected least significant difference at a level of 0.05 .

\section{Results}

\subsection{Description of Selected Backcrossing Progenies}

Among the 42 double homozygous BC2F2 lines from the cross of NW97S186 $\times$ Tutoumai A $(\mathrm{N} / \mathrm{T})$, seven were the AABB genotype, where ' $\mathrm{A}$ ' represents the PHS-resistance allele of TaPHS1 and ' $\mathrm{B}$ ' represents the PHS-resistance allele of TaMKK3- $A$, 11 lines were AAbb genotype, 15 lines were aaBB genotype and nine lines were aabb genotype, where ' $a$ ' represents the PHS-susceptibility allele of TaPHS1 and ' $b$ ' represents the PHS-susceptibility allele of TaMKK3-A. Among the 44 BC2F2 lines from the cross of NW97S186 $\times$ AUS1408 (N/A), 18 lines were AABB genotype, nine lines were AAbb genotype, 11 lines were aaBB genotype and six lines were aabb genotype.

In each backcross population, the germination rate of the parents was similar to the extreme germination rates in the selected progenies (Table 1), indicating the lack of transgressive segregation and that Tutoumai A or AUS1408 contributed all the PHS resistance alleles in those crosses. In each experiment, the mean germination rates were similar between the two backcrossing populations. The highest mean germination rates of $68.7 \%$ and $58.1 \%$ were observed in the N/T and N/A populations, respectively, in the spring greenhouse experiment, while the lowest mean germination rates of $34.2 \%$ and $34.8 \%$ were observed in the N/T and N/A populations, respectively, in the Manhattan field experiment. In general, the greenhouse experiments had larger standard deviation in germination rates than the field experiments, indicating that the growing environments greatly influence the expression of those PHS resistance genes (Table 1). 
Table 1. Summary of germination rates of NW97S186, Tutoumai A, AUS1408 and their selected backcross progenies in the 2015 fall and 2016 spring greenhouse experiments (GH_Fall and GH_Spring) and in the 2016 Manhattan and Hays, KS, field experiments.

\begin{tabular}{|c|c|c|c|c|c|}
\hline Population & Statistics/Parents & GH_Fall & GH_Spring & Field_MH & Field_Hays \\
\hline \multirow{5}{*}{$\begin{array}{l}\text { Selected } \mathrm{BC}_{2} \mathrm{~F}_{\mathrm{n}} \\
\text { of } \mathrm{N} / \mathrm{T} \text { cross }\end{array}$} & Mean & 0.44 & 0.69 & 0.34 & 0.51 \\
\hline & Standard Deviation & 0.21 & 0.23 & 0.17 & 0.16 \\
\hline & Range & $0.07-0.92$ & $0.24-0.99$ & $0.08-0.82$ & $0.23-0.81$ \\
\hline & NW97S186 & 0.82 & 0.98 & 0.67 & 0.91 \\
\hline & Tutoumai A & 0.03 & 0.15 & 0.21 & 0.10 \\
\hline \multirow{5}{*}{$\begin{array}{l}\text { Selected } \mathrm{BC}_{2} \mathrm{~F}_{n} \\
\text { of N/A cross }\end{array}$} & Mean & 0.43 & 0.58 & 0.35 & 0.50 \\
\hline & Standard Deviation & 0.19 & 0.20 & 0.15 & 0.17 \\
\hline & Range & $0.08-0.80$ & $0.29-0.96$ & $0.05-0.69$ & $0.10-0.77$ \\
\hline & NW97S186 & 0.74 & 0.86 & 0.67 & 0.66 \\
\hline & AUS1408 & 0.10 & 0.17 & 0.00 & 0.07 \\
\hline
\end{tabular}

${ }^{\dagger}$ Selected double homozygous $\mathrm{BC}_{2} \mathrm{~F}_{2}$ were used to evaluate germination rate in the 2015 fall greenhouse experiment (GH_Fall), $\mathrm{BC}_{2} \mathrm{~F}_{3}$ in the 2016 spring greenhouse experiment (GH_Spring) and $\mathrm{BC}_{2} \mathrm{~F}_{4}$ in the 2016 Manhattan $(\mathrm{MH})$ and Hays field experiments. N/T and N/A represent crosses of NW97S186 $\times$ Tutoumai A and NW97S186 $\times$ AUS1408, respectively.

\subsection{Effects of TaPHS1 and TaMKK3-A Genes on PHS Resistance in the Greenhouse and Field Experiments}

Overall ANOVA revealed that environments, gene sources and genotypes (TaPHS1 and TaMKK3- $A$ ) could explain $56.4 \%$ of the phenotypic variance for PHS resistance. Environment and genotype main effects, as well as environment by TaPHS1, environment by TaMKK3- $A$ and environment by gene source by TaPHS1 interactions had significant effects on PHS resistance (Table 2). Therefore, the main effect of TaPHS1 from each donor need to be investigated under different environments, whereas the effect of TaMKK3- $A$ could be estimated in the four environments without considering the sources of the donors.

Table 2. Overall analysis of variance (ANOVA) of germination rates of the selected backcross progenies of NW97S186/Tutoumai A and NW97S186/AUS1408 in the 2015 fall and 2016 spring greenhouse experiments and in the 2016 Manhattan and Hays, KS, field experiments.

\begin{tabular}{|c|c|c|c|c|c|}
\hline Source $^{\dagger}$ & $\begin{array}{l}\text { Degree of } \\
\text { Freedom }\end{array}$ & $\begin{array}{c}\text { Type III Sum } \\
\text { Square }\end{array}$ & Mean square & $F$-Value & $\operatorname{Pr}>F$ \\
\hline Env & 3 & 0.972 & 0.972 & 52.72 & $<0001 *$ \\
\hline GeneS & 1 & 0.021 & 0.021 & 0.94 & 0.3324 \\
\hline Env * GeneS & 3 & 0.017 & 0.017 & 0.94 & 0.4224 \\
\hline TaPHS1 & 1 & 1.839 & 1.839 & 84.01 & $<0001 *$ \\
\hline Env * TaPHS1 & 3 & 0.238 & 0.238 & 6.40 & 0.0003 * \\
\hline GeneS * TaPHS1 & 1 & 0.006 & 0.006 & 0.27 & 0.6039 \\
\hline Env ${ }^{*}$ GeneS $*$ TaPHS1 & 3 & 0.252 & 0.252 & 4.99 & $0.0021 *$ \\
\hline TaMKK3-A & 1 & 1.591 & 1.591 & 72.66 & $<0001 *$ \\
\hline Env * TaMKK3-A & 3 & 0.315 & 0.315 & 5.19 & 0.0016 * \\
\hline GeneS * TaMKK3-A & 1 & 0.072 & 0.072 & 3.31 & 0.0699 \\
\hline Env * GeneS * TaMKK3-A & 3 & 0.000 & 0.000 & 0.02 & 0.9953 \\
\hline TaPHS1 * TaMKK3-A & 1 & 0.079 & 0.079 & 3.63 & 0.0578 \\
\hline Env ${ }^{*}$ TaPHS1 * TaMKK3-A & 3 & 0.002 & 0.002 & 0.56 & 0.644 \\
\hline GeneS $*$ TaPHS1 * TaMKK3-A & 1 & 0.011 & 0.011 & 0.51 & 0.476 \\
\hline Env * GeneS * TaPHS1 * TaMKK3-A & 3 & 0.107 & 0.036 & 1.63 & 0.182 \\
\hline Error & 312 & 6.83 & 0.02 & - & - \\
\hline
\end{tabular}

${ }^{\dagger}$ Env $=$ environment, GeneS = gene source. ${ }^{*}$ Significant effects at the level of 0.05 .

Overall effects of TaPHS1 from Tutoumai A were significant on PHS resistance in the spring and fall greenhouse experiments with $29.4 \%$ and $22.5 \%$ reduction in germination rates, respectively (Figure 1). However, the effects of TaPHS1 from AUS1408 were significant in the spring greenhouse experiment and both Manhattan and Hays field experiments had 26.5\%, 14.4\% and 18.7\% reduction in germination rates, respectively (Figure 1). When the phenotypic data were compared between the genotypes with the contrasting alleles at TaPHS1 (AAbb and aabb), Tutoumai A reduced 23.4, 
26.5 and $8.3 \%$ germination rates in the fall and spring greenhouse and Manhattan field experiments, respectively. The significant reduction for TaPHS1 from AUS1408 was 29.0, 8.7 and 15.4\% in the spring greenhouse and Manhattan and Hays field experiments, respectively. TaMKK3- $A$ from Tutoumai A showed significant overall effects on PHS resistance in the spring $(21.4 \%)$ and fall greenhouse $(26.7 \%)$ experiments and Manhattan (12.5\%) and Hays (9.3\%) field experiments and TaMKK3-A from AUS1408 showed significant reduction in germination rate in the spring $(16.2 \%)$ and fall greenhouse $(19.1 \%)$ and Manhattan field (6.7\%) experiments (Figure 2). When the phenotypic data were compared between the genotypes with the contrasting alleles at TaPHS1 (aaBB and aabb), the resistance allele from Tutoumai A reduced 27.6, 18.5 and 14.0\% germination rates in the fall and spring greenhouse and Manhattan field experiments, respectively, whereas the significant reduction for TaPHS1 from AUS1408 was 7.8 and $18.7 \%$ for the fall and spring greenhouse experiments, respectively (Table 3 ).

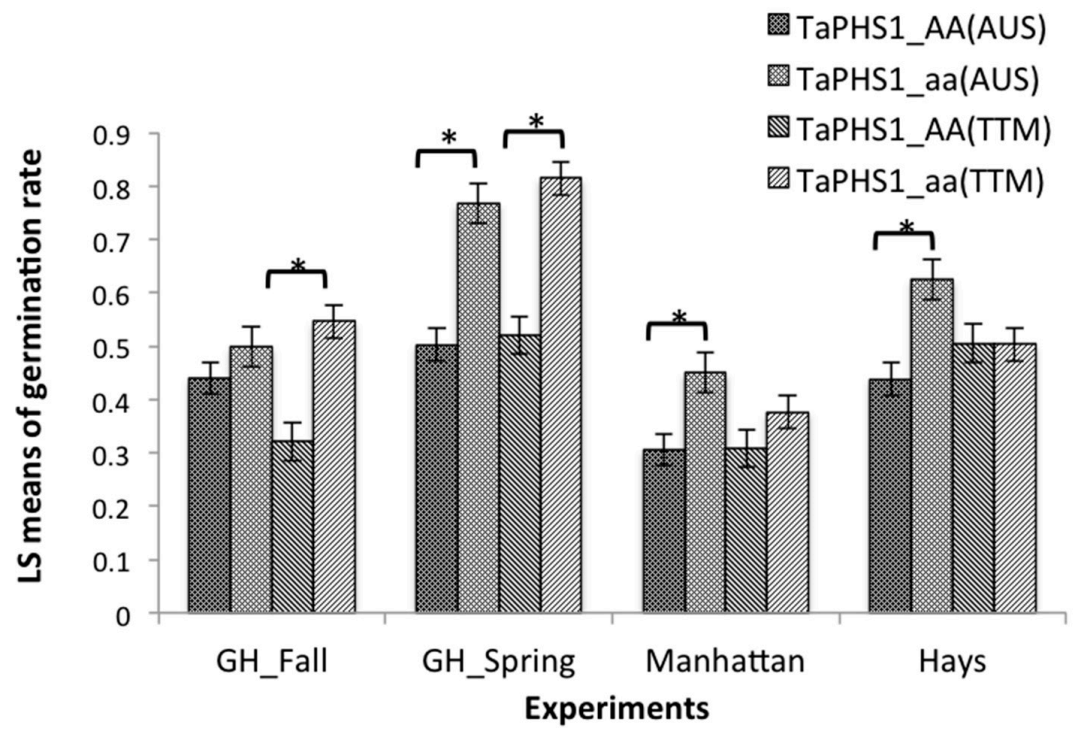

Figure 1. Effects of TaPHS1 gene from AUS1408 and Tutoumai A on germination rates evaluated in the 2015 fall and 2016 spring greenhouse experiments (GH_Fall and GH_Spring) and in the 2016 Manhattan and Hays, KS, field experiments. * Significant differences between least square means of germination rate at $p<0.05$.

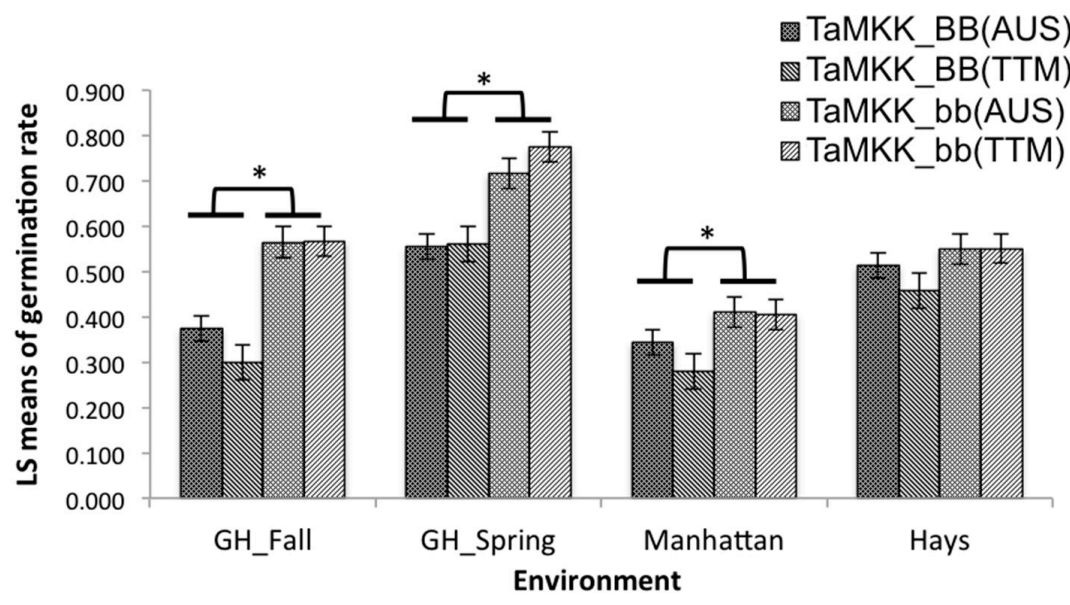

Figure 2. Effects of TaMKK3- $A$ gene on germination rates evaluated in the 2015 fall and 2016 spring greenhouse experiments (GH_Fall and GH_Spring) and in the 2016 Manhattan and Hays, KS, field experiments. ${ }^{*}$ Significant differences between least square means of germination rate between combined groups (indicated by black horizontal lines above the bars) at $p<0.05$. 
Table 3. Combined genetic effects of TaPHS1 and TaMKK3-A genes from Tutoumai A and AUS1408 in both greenhouse and field experiments in Manhattan (MH) and Hays, KS.

\begin{tabular}{cccccc}
\hline Population & Genotype & GH_Fall & GH_Spring & 2016 MH & 2016 Hays \\
\hline & AABB & $0.192^{\mathrm{a}+\dagger}$ & $0.399^{\mathrm{a}}$ & $0.253^{\mathrm{a}}$ & $0.421^{\mathrm{a}}$ \\
Selected BC ${ }_{2} \mathrm{~F}_{\mathrm{n}}$ & AAbb & $0.450^{\mathrm{b}}$ & $0.642^{\mathrm{b}}$ & $0.363^{\mathrm{a}}$ & $0.589^{\mathrm{a}}$ \\
of N/T cross $^{+}$ & aaBB & $0.408^{\mathrm{b}}$ & $0.722^{\mathrm{b}}$ & $0.306^{\mathrm{a}}$ & $0.494^{\mathrm{a}}$ \\
& $\mathrm{aabb}$ & $0.684^{\mathrm{c}}$ & $0.907^{\mathrm{c}}$ & $0.446^{\mathrm{a}}$ & $0.511^{\mathrm{a}}$ \\
\hline & AABB & $0.288^{\mathrm{a}}$ & $0.435^{\mathrm{a}}$ & $0.243^{\mathrm{a}}$ & $0.404^{\mathrm{a}}$ \\
Selected BC ${ }_{2} \mathrm{~F}_{\mathrm{n}}$ & AAbb & $0.591^{\mathrm{b}}$ & $0.571^{\mathrm{ab}}$ & $0.367^{\mathrm{ab}}$ & $0.472^{\mathrm{ab}}$ \\
of N/A cross $^{\dagger}$ & aaBB & $0.460^{\mathrm{b}}$ & $0.674^{\mathrm{b}}$ & $0.444^{\mathrm{b}}$ & $0.623^{\mathrm{b}}$ \\
& aabb & $0.538^{\mathrm{b}}$ & $0.861^{\mathrm{b}}$ & $0.454^{\mathrm{b}}$ & $0.626^{\mathrm{b}}$ \\
\hline
\end{tabular}

${ }^{\dagger}$ Selected homozygous $\mathrm{BC}_{2} \mathrm{~F}_{2}$ were used to evaluate germination rate in the 2015 fall greenhouse experiment (GH_Fall), $\mathrm{BC}_{2} \mathrm{~F}_{3}$ in the 2016 spring greenhouse experiment (GH_Spring) and $\mathrm{BC}_{2} \mathrm{~F}_{4}$ in the 2016 Manhattan (2016MH) and Hays (2016Hays), KS, field experiments. ${ }^{+\dagger}$ Comparisons were made between genotypes within each gene source and each experiment and different letters indicate statistical difference at the significant level of 0.05.

\subsection{Combined Genetic Effects of TaPHS1 and TaMKK3-A}

The combined effects of TaPHS1 and TaMKK3-A varied with different gene sources across environments. In the $\mathrm{N} / \mathrm{T}$ population, the combined effect was significant in the greenhouse experiments but not in the field experiments. In the greenhouse experiments, adding either of the resistance genes (AA or $\mathrm{BB}$ ) significantly reduced germination rates given a certain genotype of another gene and a more reduction in germination rate was observed when a wheat line carried both resistance genes compared to a line with only a single gene (Table 3). In the N/A population, the combined effect was significant in all the experiments. Adding the TaMKK3- $A$ gene alone did not significantly decrease germination rate in all the experiments and adding the TaPHS1 gene only significantly decreased germination rate in the fall greenhouse experiment with the presence of resistance allele of TaMKK3-A (Table 3). The effect of combining TaPHS1 with TaMKK3-A on PHS resistance was larger in the greenhouse experiments than in the field experiments, suggesting that the greenhouse conditions were more favorable to the expression of both genes in this study.

\section{Discussion}

PHS resistance is a complex trait that is not only controlled by seed dormancy (SD) $[17,24]$ but also affected by GC $[1,25]$, spike morphology, as well as environmental factors such as temperature, moisture and photoperiod after flowering $[26,27]$. In this study, we were able to study the combined genetic effects and gene-by-environment interactions between TaPHS1 and TaMKK3- $A$ from different genetic backgrounds using gene markers, the results provided more comprehensive understanding of those gene effects than previous studies [28,29]. In addition, we used all white-grained wheat lines as experimental materials, which excluded GC effect on PHS resistance. We demonstrated that both cloned genes, TaPHS1 and TaMKK3- $A$, for PHS resistance showed significant interactions with the environments (Table 2). On average, larger individual and combined effects of the two genes were detected in the greenhouse than in the field. This observation was possibly due to the fact that the plants had an extended maturation period under greenhouse conditions where temperature is less variable than in summer field experiments. In addition, TaMKK3- $A$ showed a larger effect in the fall greenhouse experiment than in other experiments (Figure 2), suggesting that lower temperature might up-regulate the expression of 4A QTL [30]. However, TaPHS1 was more effective on reducing germination rate for plants grown in the spring greenhouse where temperature for wheat seed development was higher than the fall greenhouse (Figure 1), which was contradictory to the previous result that low temperature during seed development increased TaPHS1 expression level [4]. Other environmental factors such as humidity, photoperiod or light quality might also contribute to such a discrepancy, because the TaPHS1 gene is likely to respond to those environmental factors as FT-like and TFL1-like genes did in other species [3,4,31,32]. TaPHS1 and TaMKK3- $A$ demonstrated 
various effects on germination rates (Figures 1 and 2) in the two field experiments where they had similar temperatures but different precipitations, indicating that humidity might also play an important role in affecting those gene expressions. The epistatic effects between TaPHS1 and TaMKK3-A on PHS resistance was only marginally significant $(p=0.058)$ across experiments. It remains to be determined if the epistasis play important roles in the PHS resistance regulatory pathways.

Significant effects of environment-by-gene source of TaPHS1 was observed in this study. In the fall greenhouse experiment, TaPHS1 from Tutoumai A significantly reduced germination rates, whereas TaPHS1 from AUS1408 did not (Table 3) although they carry identical sequence. However, the result was opposite in the two field experiments. Considering other minor QTLs might be present in the two sources, it is likely that TaPHS1 might have interacted with other QTLs in both Tutoumai A background and AUS1408 background.

TaPHS1 and TaMKK3-A are the two major genes cloned for PHS resistance. This study showed that one gene may not provide adequate protection from PHS in some environments due to the significant genotype-by-environment interactions. Although the total additive effect of the two genes also varied with the environments, pyramiding both genes could significantly reduce germination rates in most environments tested and could be more effective in protecting wheat plants from PHS in regions with mild climate conditions during maturation (Table 3). Gene markers for TaPHS1 and TaMKK3-A have been shown to be useful in MAB, thus they can be applied in breeding to select these two genes to improve PHS resistance. However, in this study, the selected backcrossing progenies with both resistance genes still showed higher average germination rates than their PHS-resistant donors in most experiments (Tables 1 and 3), suggesting that other minor genes in both donor parents might also be important for reducing PHS [33]. Identifying and accumulating natural mutations and the non-grain color related resistance QTLs with TaPHS1 and TaMKK3-A could greatly enhance the PHS resistance in white wheat $[3,19]$.

Supplementary Materials: The following are available online at http:/ / www.mdpi.com/2073-4395/8/10/210/s1, Figure S1: A workflow diagram of the backcrossing project to transfer quantitative trait loci (QTLs) on 3AS and 4AL from Tutoumai A and AUS1408 to NW97S186, Table S1: Environmental statistics of 2015 fall and 2016 spring greenhouse experiments (GH_Fall and GH_Spring) and field experiments conducted in Manhattan (2016MH) and Hays (2016Hays), KS, USA in 2015-2016 growing season, Table S2: List of KASPar primers used for genotyping and marker-assisted selection.

Author Contributions: G.B. conceived and designed the research, M.L., G.Z. and S.L. conducted experiments and M.L. and G.B. wrote the manuscript. All authors have revised the manuscript and approved the final version.

Funding: This research was funded by the National Research Initiative Competitive Grants 2017-67007-25939 and 2017-67007-25929 from the U.S. Department of Agriculture National Institute of Food and Agriculture.

Acknowledgments: This is contribution number 18-350-J from the Kansas Agricultural Experiment Station. This project is partly funded Mention of trade names or commercial products in this publication is solely for the purpose of providing specific information and does not imply recommendation or endorsement by the USDA. USDA is an equal opportunity provider and employer.

Conflicts of Interest: The authors declare no conflict of interest.

\section{References}

1. Groos, C.; Gay, G.; Perretant, M.R.; Gervais, L.; Bernard, M.; Dedryver, F.; Charmet, G. Study of the relationship between pre-harvest sprouting and grain color by quantitative trait loci analysis in a white $\times$ red grain bread-wheat cross. Theor. Appl. Genet. 2002, 104, 39-47. [CrossRef] [PubMed]

2. Mares, D.; Mrva, K.; Cheong, J.; Williams, K.; Watson, B.; Storlie, E.; Sutherland, M.; Zou, Y. A QTL located on chromosome $4 \mathrm{~A}$ associated with dormancy in white- and red-grained wheats of diverse origin. Theor. Appl. Genet. 2005, 111, 1357-1364. [CrossRef] [PubMed]

3. Nakamura, S. Grain dormancy genes responsible for preventing pre-harvest sprouting in barley and wheat. Breed. Sci. 2018, 68, 295-304. [CrossRef] [PubMed] 
4. Nakamura, S.; Abe, F.; Kawahigashi, H.; Nakazono, K.; Tagiri, A.; Matsumoto, T.; Utsugi, S.; Ogawa, T.; Handa, H.; Ishida, H.; et al. A wheat homolog of MOTHER OF FT AND TFL1 acts in the regulation of germination. Plant Cell 2011, 23, 3215-3229. [CrossRef] [PubMed]

5. Liu, S.; Sehgal, S.K.; Li, J.; Lin, M.; Trick, H.N.; Yu, J.; Gill, B.S.; Bai, G. Cloning and characterization of a critical regulator for preharvest sprouting in wheat. Genetics 2013, 195, 263-273. [CrossRef] [PubMed]

6. Torada, A.; Koike, M.; Ogawa, T.; Takenouchi, Y.; Tadamura, K.; Wu, J.; Matsumoto, T.; Kawaura, K.; Ogihara, Y. A causal gene for seed dormancy on wheat chromosome 4A encodes a MAP kinase kinase. Curr. Biol. 2016, 26, 782-787. [CrossRef] [PubMed]

7. Liu, S.; Cai, S.; Graybosch, R.; Chen, C.; Bai, G. Quantitative trait loci for resistance to pre-harvest sprouting in US hard white winter wheat Rio Blanco. Theor. Appl. Genet. 2008, 117, 691-699. [CrossRef] [PubMed]

8. Liu, S.; Sehgal, S.K.; Lin, M.; Li, J.; Trick, H.N.; Gill, B.S.; Bai, G. Independent mis-splicing mutations in TaPHS1 causing loss of preharvest sprouting (PHS) resistance during wheat domestication. New Phytol. 2015, 208, 928-935. [CrossRef] [PubMed]

9. Kato, K.; Nakamura, W.; Tabiki, T.; Miura, H. Detection of loci controlling seed dormancy on group 4 chromosomes of wheat and comparative mapping with rice and barley genomes. Theor. Appl. Genet. 2001, 102, 980-985. [CrossRef]

10. Mares, D.J.; Mrva, K. Mapping quantitative trait loci associated with variation in grain dormancy in Australian wheat. Crop Pasture Sci. 2001, 52, 1257-1265. [CrossRef]

11. Torada, A.; Ikeguchi, S.; Koike, M. Mapping and validation of PCR-based markers associated with a major QTL for seed dormancy in wheat. Euphytica 2005, 143, 251-255. [CrossRef]

12. Chen, C.X.; Cai, S.B.; Bai, G.H. A major QTL controlling seed dormancy and pre-harvest sprouting resistance on chromosome 4A in a Chinese wheat landrace. Mol. Breed. 2008, 21, 351-358. [CrossRef]

13. Ogbonnaya, F.C.; Imtiaz, M.; Ye, G.; Hearnden, P.R.; Hernandez, E.; Eastwood, R.F.; van Ginkel, M.; Shorter, S.C.; Winchester, J.M. Genetic and QTL analyses of seed dormancy and preharvest sprouting resistance in the wheat germplasm CN10955. Theor. Appl. Genet. 2008, 116, 891-902. [CrossRef] [PubMed]

14. Singh, R.; Matus-Cádiz, M.; Båga, M.; Hucl, P.; Chibbar, R.N. Identification of genomic regions associated with seed dormancy in white grained wheat. Euphytica 2010, 174, 391-408. [CrossRef]

15. Liu, S.; Bai, G.; Cai, S.; Chen, C. Dissection of genetic components of preharvest sprouting resistance in white wheat. Mol. Breed. 2011, 27, 511-523. [CrossRef]

16. Cabral, A.L.; Jordan, M.C.; McCartney, C.A.; You, F.M.; Humphreys, D.G.; MacLachlan, R.; Pozniak, C.J. Identification of candidate genes, regions and markers for pre-harvest sprouting resistance in wheat (Triticum aestivum L.). BMC Plant Biol. 2014, 14, 340. [CrossRef] [PubMed]

17. Anderson, J.A.; Sorrells, M.E.; Tanksley, S.D. RFLP analysis of genomic regions associated with resistance to preharvest sprouting in wheat. Crop Sci. 1993, 33, 453-459. [CrossRef]

18. Munkvold, J.D.; Tanaka, J.; Benscher, D.; Sorrells, M.E. Mapping quantitative trait loci for preharvest sprouting resistance in white wheat. Theor. Appl. Genet. 2009, 119, 1223-1235. [CrossRef] [PubMed]

19. Shao, M.; Bai, G.; Rife, T.W.; Poland, J.; Lin, M.; Liu, S.; Chen, H.; Kumssa, T.; Fritz, A.; Trick, H.; et al. QTL mapping of pre-harvest sprouting resistance in a white wheat cultivar Danby. Theor. Appl. Genet. 2018, 131, 1683-1697. [CrossRef] [PubMed]

20. Xi, W.; Liu, C.; Hou, X.; Yu, H. MOTHER OF FT AND TFL1 regulates seed germination through a negative feedback loop modulating ABA signaling in Arabidopsis. Plant Cell 2010, 22, 1733-1748. [CrossRef] [PubMed]

21. Lin, M.; Zhang, D.; Liu, S.; Zhang, G.; Yu, J.; Fritz, A.K.; Bai, G. Genome-wide association analysis on pre-harvest sprouting resistance and grain color in US winter wheat. BMC Genomics 2016, 17, 794. [CrossRef] [PubMed]

22. Zadoks, J.C.; Chang, T.T.; Konzak, C.F. A decimal code for the growth stages of cereals. Weed Res. 1974, 14, 415-421. [CrossRef]

23. Trethowan, R.M. Evaluation and selection of bread wheat (Triticum aestivum L) for preharvest sprouting tolerance. Aust. J. Agric. Res. 1995, 46, 463-474. [CrossRef]

24. Bewley, J.D.; Black, M. Physiological and Biochemistry of Seeds in Relation to Germination; Springer: Heidelberg, Germany, 1982; Volume 2, pp. 61-81.

25. Gfeller, F.; Svejda, F. Inheritance of post-harvest seed dormancy and kernel color in spring wheat lines. Can. J. Plant Sci. 1960, 40, 1-6. [CrossRef] 
26. Argel, P.J.; Humphreys, L.R. Environmental effects on seed development and hardseededness in Stylosanthes hamata cv. Verano. I. Temperature. Crop Pasture Sci. 1983, 34, 261-270. [CrossRef]

27. Ceccato, D.V.; Bertero, H.D.; Batlla, D. Environmental control of dormancy in quinoa (Chenopodium quinoa) seeds: Two potential genetic resources for preharvest sprouting tolerance. Seed Sci. Res. 2011, 21, 133-141. [CrossRef]

28. Mori, M.; Uchino, N.; Chono, M.; Kato, K.; Miura, H. Mapping QTLs for grain dormancy on wheat chromosome 3A and the group 4 chromosomes and their combined effect. Theor. Appl. Genet. 2005, 110, 1315-1323. [CrossRef] [PubMed]

29. Kottearachchi, N.S.; Uchino, N.; Kato, K.; Miura, H. Increased grain dormancy in white-grained wheat by introgression of preharvest sprouting tolerance QTLs. Euphytica 2006, 152, 421-428. [CrossRef]

30. Barrero, J.M.; Cavanagh, C.; Verbyla, K.L.; Tibbits, J.F.; Verbyla, A.P.; Huang, B.E.; Rosewarne, M.G.; Stephen, S.; Wang, P.; Whan, A.; et al. Transcriptomic analysis of wheat near-isogenic lines identifies PM19-A1 and A2 as candidates for a major dormancy QTL. Genome Biol. 2015, 16, 93. [CrossRef] [PubMed]

31. Rohde, A.; Bhalerao, R.P. Plant dormancy in the perennial context. Trends Plant Sci. 2007, 12, $217-223$. [CrossRef] [PubMed]

32. Shalit, A.; Rozman, A.; Goldshmidt, A.; Alvarez, J.P.; Bowman, J.L.; Eshed, Y.; Lifschitz, E. The flowering hormone florigen functions as a general systemic regulator of growth and termination. Proc. Natl. Acad. Sci. USA 2009, 106, 8392-8397. [CrossRef] [PubMed]

33. Tyagi, S.; Gupta, P.K. Meta-analysis of QTLs involved in pre-harvest sprouting tolerance and dormancy in bread wheat. Triticeae Genomics Genet. 2012, 3, 9-24. [CrossRef]

(C) 2018 by the authors. Licensee MDPI, Basel, Switzerland. This article is an open access article distributed under the terms and conditions of the Creative Commons Attribution (CC BY) license (http:/ / creativecommons.org/licenses/by/4.0/). 